Published in final edited form as:

Anal Chem. 2016 February 2; 88(3): 1885-1891. doi:10.1021/acs.analchem.5b04285.

\title{
Online Hydrophobic Interaction Chromatography-Mass Spectrometry for Top-down Proteomics
}

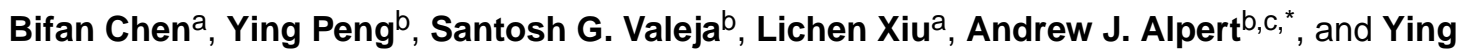 \\ $\mathrm{Ge}^{\mathrm{a}, \mathrm{b}, \mathrm{d},{ }^{*}}$ \\ aDepartment of Chemistry, University of Wisconsin-Madison, Madison, Wisconsin, USA \\ bepartment of Cell and Regenerative Biology, University of Wisconsin-Madison, Madison, \\ Wisconsin, USA \\ cPolyLC Inc., Columbia, Maryland, USA \\ dHuman Proteomics Program, School of Medicine and Public Health, University of Wisconsin- \\ Madison, Madison, Wisconsin, USA
}

\begin{abstract}
Recent progress in top-down proteomics has led to a demand for mass spectrometry (MS)compatible chromatography techniques to separate intact proteins using volatile mobile phases. Conventional hydrophobic interaction chromatography (HIC) provides high-resolution separation of proteins under non-denaturing conditions but requires high concentrations of nonvolatile salts. Herein, we introduce a series of more hydrophobic HIC materials that can retain proteins using MS-compatible concentrations of ammonium acetate. The new HIC materials appear to function as a hybrid form of conventional HIC and reverse phase chromatography. The function of the salt seems to be preserving protein structure rather than promoting retention. Online HIC-MS is feasible for both qualitative and quantitative analysis. This is demonstrated with standard proteins and a complex cell lysate. The mass spectra of proteins from the online HIC-MS exhibit low charge state distributions, consistent with those commonly observed in native mass spectrometry. Furthermore, HIC-MS can chromatographically separate proteoforms differing by minor modifications. Hence, this new HIC-MS combination is promising for top-down proteomics.
\end{abstract}

\section{Graphical Abstract}

\footnotetext{
* To whom correspondence may be addressed: Dr. Ying Ge, 1300 University Ave., SMI 130, Madison, Wisconsin 53706, USA. ge2@ wisc.edu; Tel: 608-263-9212; Fax: 608-265-5512. Dr. Andrew Alpert, PolyLC Inc., 9151 Rumsey Rd, Suite 180 Columbia, MD 21045, USA. aalpert@polylc.com; Tel: 410-992-5400; Fax: 410-730-8340.

Supporting Information Available:

Additional information as noted in the text. This material is available free of charge via the Internet at http://pubs.acs.org.
} 


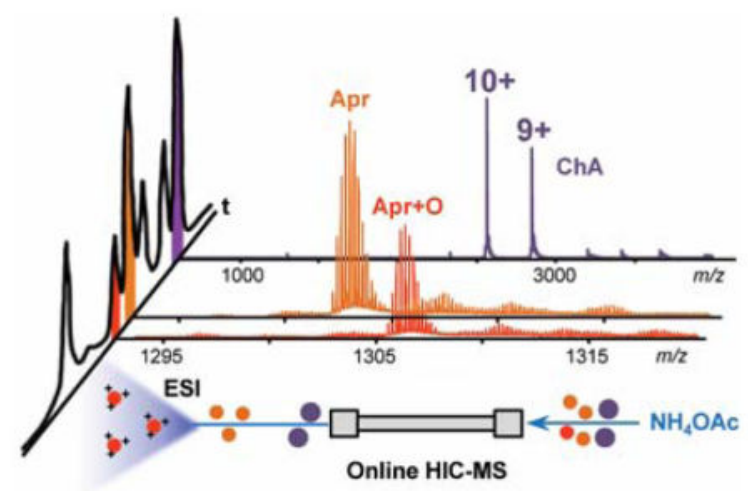

\section{INTRODUCTION}

Increasing evidence has implicated protein post-translational modifications (PTMs) in the regulation of protein function in health and disease. ${ }^{1-10}$ Although bottom-up proteomics offers high sensitivity, high throughput, and deep proteome coverage, it is suboptimal for analysis of PTMs. ${ }^{11}$ Top-down mass spectrometry (MS)-based proteomics is arguably the most powerful method for the analysis of proteoforms ${ }^{12}$, including those arising as a result of PTMs, genetic variations (e.g., polymorphisms and mutations), and alternative splicing of RNA transcripts. ${ }^{10,13-15}$ Consequently, there is a significant interest in the top-down approach. ${ }^{10,13,14,16-19}$

Nevertheless, many challenges remain for top-down proteomics, including difficulty in separating intact proteins. ${ }^{10,20}$ Liquid chromatography (LC) with volatile mobile phases is the preferred method for separation of complex mixtures because it affords online separation with direct coupling to a mass spectrometer and is amenable to automation, thus eliminating tedious fraction collection procedures and allowing for high throughput analysis. ${ }^{21}$ However, the number of chromatography methods that are compatible with this arrangement is limited. Reversed-phase chromatography (RPC) is the most popular such method. ${ }^{4,8,22-25}$ However, the conditions used in RPC denature many intact proteins, exposing numerous hydrophobic residues in the protein core. ${ }^{26-28}$ This can lead to peak broadening, low protein recovery, and failure to elute at all, with the severity depending on the RPC material used. ${ }^{26}$ Hydrophilic interaction chromatography (HILIC) has been utilized for direct coupling with MS, but HILIC can only be used to separate proteins that remain soluble in solutions containing high concentrations of organic solvent. ${ }^{29-31}$ Recent studies have demonstrated online coupling of either size exclusion chromatography (SEC) or ion exchange chromatography (IEC) with MS using a volatile buffer containing ammonium acetate $\left(\mathrm{NH}_{4} \mathrm{OAc}\right) .{ }^{32,33}$ However, SEC is not yet a high-resolution method. ${ }^{20,34}$ While IEC is a high-resolution method, complex protein mixtures often require more than one dimension of fractionation. ${ }^{35}$ Therefore, there is a need for additional methods for online LC-MS that can provide high-resolution separation of a wide range of proteins with minimal denaturation.

Hydrophobic interaction chromatography ${ }^{36}$ (HIC) is a technique that separates proteins based on hydrophobicity but with complementary selectivity to RPC and with high- 
resolution under non-denaturing conditions. ${ }^{35,37,38}$ The stationary phases used for HIC generally feature low-density and moderately hydrophobic ligands (propyl and phenyl) attached to a hydrophilic underlayer. ${ }^{37}$ Being a non-denaturing mode, HIC only interacts with a limited set of hydrophobic residues on the surface of a protein's tertiary structure. Proteins then elute in order of increasing surface hydrophobicity, with high recovery and unusually high sensitivity to conformational variation. ${ }^{36}$ In HIC, a decreasing gradient of a salt high in the Hofmeister series ${ }^{36}$ is used, typically a sulfate, phosphate, or citrate. Such salts are not compatible with MS analysis. We recently reported that ammonium tartrate provides effective separation of intact proteins when used in HIC and minimizes protein adduction and MS signal suppression as compared to the common sulfate salts. ${ }^{35,38}$ Nevertheless, ammonium tartrate is not volatile and, thus, a desalting step is necessary prior to MS analysis of the HIC eluates. Ammonium acetate $\left(\mathrm{NH}_{4} \mathrm{OAc}\right)$, on the other hand, is volatile and features reduced nonspecific sodium adduction. ${ }^{39,40}$ Unfortunately, it provides inadequate protein retention when used with conventional HIC materials, such as PolyPROPYL A. ${ }^{38}$ Using a HIC column with pentyl-ligands, Gooding et al. obtained adequate retention of proteins only with $4 \mathrm{M} \mathrm{NH}_{4} \mathrm{OAc} .{ }^{40}$ Hence, we propose to increase the hydrophobic character of the HIC stationary phase to the point that proteins are retained and eluted using $\mathrm{NH}_{4} \mathrm{OAc}$ concentrations of $1 \mathrm{M}$ or less, a range which has been previously demonstrated to be compatible with MS analysis. ${ }^{41}$ Accordingly, in this study, a series of more hydrophobic HIC materials were synthesized and characterized in search of a balance between retention and denaturation with a MS-compatible salt concentration. We have further demonstrated the feasibility of online HIC-MS for top-down proteomics using these new HIC materials.

\section{MATERIALS AND METHODS}

\section{Chemicals and reagents}

All reagents were acquired from Sigma-Aldrich Inc. (St. Louis, MO, USA) unless noted otherwise. HPLC grade water, acetonitrile (ACN), and $\mathrm{NH}_{4} \mathrm{OAc}$ were purchased from Fisher Scientific (Fair Lawn, NJ, USA).

\section{Sample preparation}

Standard protein samples (RiA, ribonuclease A from bovine pancreas; Cyt, cytochrome C from equine heart; ChA, a-chymotrypsinogen A from bovine pancreas; Lys, lysozyme from chicken egg white; Apr, aprotinin from bovine lung; Trp, trpsinogen from bovine pancreas; Lac, $\beta$-lactoglobulin B from bovine milk) were used without additional purification. HPLCgrade water was used to prepare protein standards at $10 \mathrm{mg} / \mathrm{mL}$. Subsequent dilution using 1 $\mathrm{M} \mathrm{NH}_{4} \mathrm{OAc}$ (at least 3 vols. per vol. protein solution) brought the final concentration to 0.1$0.5 \mathrm{mg} / \mathrm{mL}$ unless noted otherwise. The six-protein mixture contained RiA, Apr, Trp, Lys, ChA, and Lac, in which each protein had a final concentration to be $0.4 \mathrm{mg} / \mathrm{mL}, 0.1 \mathrm{mg} / \mathrm{mL}$, $0.5 \mathrm{mg} / \mathrm{mL}, 0.1 \mathrm{mg} / \mathrm{mL}, 0.4 \mathrm{mg} / \mathrm{mL}$, and $0.5 \mathrm{mg} / \mathrm{mL}$ respectively.

Escherichia coli (E. coli) cell pellet from the BL21 strain grown in-house was suspended in lysis buffer containing $50 \mathrm{mM}$ HEPES, $150 \mathrm{mM} \mathrm{NaCl}, 0.1 \% \mathrm{NP}-40$, and $1 \mathrm{x}$ protease and phosphatase inhibitor cocktail tablets (Roche, Penzburg, Germany) with the ratio of pellet to 
buffer being 1:10 $(\mathrm{mg} / \mu \mathrm{L})$. The suspension was sonicated to lyse the cells, and was subsequently centrifuged at $10,400 \mathrm{~g}, 4^{\circ} \mathrm{C}$ for $20 \mathrm{~min}$. The resulting lysate (supernatant) was centrifuged 5 times with $10 \mathrm{kDa}$ ultracentrifugal filters at $4{ }^{\circ} \mathrm{C}$ for $5 \mathrm{~min}$ at $16,100 \mathrm{~g}$ with $1 \mathrm{M} \mathrm{NH}_{4} \mathrm{OAc}$. The supernatant solution containing soluble proteins from $E$. coli cell lysate was utilized directly for online HIC-MS analysis.

\section{HIC materials}

In addition to the existing PolyPROPYL A and PolyBUTYL A materials, ${ }^{37}$ PolyPENTYL A, PolyHEXYL A, PolyHEPTYL A, PolyOCTYL A, PolyNONYL A, PolyDECYL A, and PolyHYDROXYDECYL A were synthesized at PolyLC Inc. (Columbia, MD, USA). The resulting coatings are polyasparagines with functional side chains of various lengths as indicated by the names. The stationary phase materials were slurry-packed into $100 \mathrm{~mm} \times$ $4.6 \mathrm{~mm}$ i.d. stainless steel columns for initial experiments with HPLC-UV, and $100 \mathrm{~mm} \times$ $0.2 \mathrm{~mm}$ i.d. capillary columns for online HIC-MS analysis. Initial studies and optimization were performed using an Essence LC system from Scientific Systems Inc. (State College, PA, USA). The flow rate was $1.0 \mathrm{~mL} / \mathrm{min}$ and UV absorbance detection was at $280 \mathrm{~nm}$.

\section{HIC-MS}

$100 \mathrm{~mm} \times 0.2 \mathrm{~mm}$ i.d. PolyHEXYL A and PolyHEPTYL A capillaries were used on a Bruker Nano-Advance HPLC system (Fremont, CA, USA). Mobile phase A (MPA) contained $1 \mathrm{M} \mathrm{NH}_{4} \mathrm{OAc}$ and mobile phase $\mathrm{B}$ (MPB) contained $20 \mathrm{mM} \mathrm{NH}_{4} \mathrm{OAc}$ (overall) in 50:50 water/ACN without any adjustment of $\mathrm{pH}$. A 15 min linear gradient (from 100\% MPA to $100 \% \mathrm{MPB}$ ) followed by $100 \%$ MPB for $5 \mathrm{~min}$ and $100 \%$ MPA for another $5 \mathrm{~min}$ was used at a flow rate of 3.0 or $2.4 \mu \mathrm{L} / \mathrm{min} .2 \mu \mathrm{L}$ of sample were injected for all the HIC-MS runs. Samples eluted from HIC columns were electrosprayed into a MaXis Plus Q-TOF mass spectrometer (Bruker Daltonics, Bremen, Germany). End plate offset and capillary voltage were optimized at $500 \mathrm{~V}$ and $4000 \mathrm{~V}$, respectively. The nebulizer was set to $1.5 \mathrm{bar}$, and the dry gas flow rate was $4.0 \mathrm{~L} / \mathrm{min}$ at $200{ }^{\circ} \mathrm{C}$. Mass range was set to $200-2800 \mathrm{~m} / \mathrm{z}$ initially and $100-6000 \mathrm{~m} / \mathrm{z}$ for subsequence runs to see lower charge states. The quadruple low mass was set to $1600 \mathrm{~m} / \mathrm{z}$. All data were collected using Hystar 3.2 and otofControl 3.4 (Bruker Daltonics). The total HIC-MS data run was 25 min per sample. All data were analyzed and chromatograms were smoothed using Compass DataAnalysis 4.3. Maximum Entropy was used as the deconvolution algorithm (resolution was set below 40,000).

\section{RESULTS}

\section{Conventional $\mathrm{HIC}$ columns with the volatile salt $\mathrm{NH}_{4} \mathrm{OAC}$}

The performance of $\mathrm{NH}_{4} \mathrm{OAc}$ was first evaluated with columns of the existing HIC materials PolyPROPYL A and PolyBUTYL A to estimate the concentration of $\mathrm{NH}_{4} \mathrm{OAc}$ necessary for retention and to assess the effect of ligand length. With PolyPROPYL A, a gradient starting with concentrations of $\mathrm{NH}_{4} \mathrm{OAc}$ ranging from 0.5-1 $\mathrm{M}$ resulted in elution of $\mathrm{RiA}$ and $\mathrm{ChA}$ in the void volume (Figure 1a). ChA was slightly retained when starting with $2.5 \mathrm{M}$ $\mathrm{NH}_{4} \mathrm{OAc}$ (Figure 1a), but such a high concentration of salt is impractical for online LC-MS analysis since it could overwhelmingly suppress protein signals. With the slightly more hydrophobic PolyBUTYL A, retention and separation of RiA and ChA was improved but 
still inadequate (Figure 1b). Retention decreased between 2.5 and $0.75 \mathrm{M}$ salt, as expected, but retention of ChA increased again with $0.5 \mathrm{M}$ salt concentration. At this low concentration of salt, the hydrophobic residues in the core may be exposed to the stationary phase, ${ }^{42}$ leading to increased retention and peak broadening. We speculated that a rather high initial salt concentration would be needed to preserve the tertiary structure.

\section{Characterization of a series of new HIC materials}

We first tested solvent conditions for PolyPENTYL A (Figure 2a). A typical HIC gradient from $2.5 \mathrm{M}$ to $20 \mathrm{mM} \mathrm{NH}_{4} \mathrm{OAc}$ resulted in no elution of Lys even after a subsequent gradient to $20 \mathrm{mM} \mathrm{NH}_{4} \mathrm{OAc}$ with $50 \% \mathrm{ACN}$ (Figure $2 \mathrm{a}$ i; an $\mathrm{A} \rightarrow \mathrm{B} \rightarrow \mathrm{C}$ solvent sequence). We next used a reversed-phase-type gradient, from $20 \mathrm{mM} \mathrm{NH}_{4} \mathrm{OAc}$ to $20 \mathrm{mM} \mathrm{NH}_{4} \mathrm{OAc}$ with $50 \% \mathrm{ACN}$ (a B $\rightarrow \mathrm{C}$ solvent sequence), which also failed to elute Lys (Figure 2a ii). Elution of Lys was only observed in the 15-min time frame in a well-shaped peak when the organic solvent was introduced at the same time that the salt concentration was decreased (Figure 2a iii; an $\mathrm{A} \rightarrow \mathrm{C}$ solvent sequence). Therefore, with the new HIC materials some organic solvent seems to be required in any mobile phase used for a gradient for the elution of some proteins in a reasonable time frame. With a higher concentration of ACN in the final mobile phase, Lys eluted earlier, as expected (Figure S1). A comparison across all new HIC materials shows no appreciable increase in retention time of Lys in its native structure (Figure 2b). However, with the more hydrophobic materials, an increasing percentage of the Lys sample is seen in a broad and later-eluting peak which probably corresponds to a denatured form. With a RiA and ChA mixture, retention increased significantly when going from PolyBUTYL A to PolyPENTYL A (Figure 2c); but retention times did not change significantly with a further increase in ligand length (Figure 2b). Additionally, high concentrations of $\mathrm{NH}_{4} \mathrm{OAc}$ did not increase retention of these protein standards by the more hydrophobic materials in the series (Figure S2). These properties are usually associated with RPC rather than conventional HIC. Our data imply that the function of a high salt concentration is most likely to preserve protein structure, since starting at low salt concentration resulted in partial or no elution. At least $0.75 \mathrm{M}$ of $\mathrm{NH}_{4} \mathrm{OAc}$ was required for this with the standards RiA and ChA (Figure S2).

As noted previously, with increasing hydrophobicity of the stationary phase there is a tendency for some proteins to be denatured upon contact despite the protective effect of the $\mathrm{NH}_{4} \mathrm{OAc} .{ }^{43}$ Denaturation typically results in later elution or no elution at all. Our data indicate that susceptibility to this phenomenon varied with different proteins. Cyt eluted as a well-shaped peak from PolyPENTYL A but was retained much more strongly on PolyHEXYL A and PolyHEPTYL A (Figure S3). Lys and RiA exhibited a similar trend starting with PolyOCTYL A, whereas ChA seems to have withstood contact even with PolyDECYL A (Figure 2c). Thus, the choice of HIC material to use can vary depending on the proteins. For example, an antibody-drug conjugate containing several molecules of a hydrophobic drug should probably be run on a less hydrophobic column (cf. PolyPENTYL A) than for a hydrophilic protein such as cytochrome C. However, the mass spectra of these proteins suggest that the later elution does not necessarily reflect denaturation (Figure S4). The performance of the PolyHYDROXYDECYL A material was similar to that of PolyBUTYL A [data not shown], and it was not considered further. 


\section{Online HIC-MS of standard proteins}

Based on these initial studies, to minimize denaturation and ensure adequate separation, we chose capillaries of PolyHEXYL A, PolyHEPTYL A, and PolyPENTYL A, $100 \mathrm{~mm} \times$ 0.2$\mathrm{mm}$, for online HIC-MS experiments. We first examined a single protein, Lys, in a $15 \mathrm{~min}$ gradient from $1 \mathrm{M} \mathrm{NH}_{4} \mathrm{OAc}$ to $20 \mathrm{mM} \mathrm{NH}_{4} \mathrm{OAc}$ containing $50 \% \mathrm{ACN}$. The base peak chromatogram featured a well-retained peak with minimal denaturation (Figure 3a). The average mass spectrum of the peak demonstrated the detection of Lys and the distribution of the charge states fell predominantly at low charge states $(8+, 7+$, and $6+)$, characteristic of a native mass spectrum of non-denatured proteins. ${ }^{41,44}$ The zoom-in mass spectrum of highlighted charge state $8+$ showed the high-resolution isotopomer envelope of Lys and minimal adduction of $\mathrm{Na}^{+}$. This result demonstrates the feasibility of the online HIC-MS method and the minimization of denaturation. Subsequently we subjected the Lys sample to serial dilution and assessed reproducibility and quantitation of HIC-MS. The area under the peak of each chromatogram in all runs was plotted against the corresponding Lys concentration. Overlaid chromatograms exhibited consistent retention time (Figure 3b), and the coefficient of determination $\left(\mathrm{R}^{2}\right)$ of the working curve in regression analysis, $99.9 \%$, which demonstrated that HIC-MS can be used for protein quantitation (Figure 3c).

The practicality of this online HIC-MS method was further established with a mixture of six protein standards: RiA, Apr, Trp, Lys, ChA, and Lac. The six-protein standards were well separated in clean peaks with a PolyHEPTYL A capillary (Figure 4). Comparison of the overlaid HIC-MS chromatograms of individual standard proteins (Figure 4a) and the HICMS chromatogram of the six-protein mixture (Figure 4b) confirmed the identities of the peaks as well as the consistency of their retention times. The mass spectrum of each protein possessed a distinctive low charge state pattern with minimal adduction, typical of native MS. ${ }^{41,44}$ They were deconvoluted to calculate the theoretical intact masses as shown (Figure 4c). A comparison of PolyPENTYL A, PolyHEXYL A, and PolyHEPTYL A using the same six-protein mixture confirmed the earlier observation that the ligand length of the new HIC materials does not affect retention time significantly for most of these standards, but Lac proved to be an exception (Figure S5).

Notably, the standard Apr eluted in two separate peaks from PolyHEPTYL A. The earliereluting one was likely to be an oxidized form of Apr because the species from the two peaks had a 15.98 Da mass difference after deconvolution (Figure 5). This well exemplified that HIC is sensitive for small conformational variations. ${ }^{45,46}$ While the HIC-MS data confirm the significantly later elution of Cyt from PolyHEPTYL A than from PolyPENTYL A, the mass spectra exhibited the same charge state distribution (Figure S4). This suggests that Cyt elutes from both materials predominantly in its native conformation. In addition, we have demonstrated the orthogonal selectivity between HIC-MS and RPC-MS using the six-protein mixture. The eluting order from RPC-MS (Apr, Lys, RiA, Trp, ChA, Lac) differs from that we observed in HIC-MS (RiA, Apr, Trp, Lys, ChA, Lac) (Figure S6).

\section{Online HIC-MS on E.coli lysate}

We further evaluated online HIC-MS with a complex E.coli cell lysate. Figure 6a shows the ten-fold magnified total ion chromatogram (TIC) of HIC-MS of the lysate, in which the 
most hydrophilic proteins eluted immediately in a broad peak ( $2.5-5 \mathrm{~min})$. The overall pattern of the TIC resembles the HIC UV chromatogram of $E$. coli lysate using ammonium tartrate and a PolyPROPYL A column as published previously. ${ }^{38}$ Representative mass spectra (Figure $6 \mathrm{~b}-\mathrm{e}$ ) display proteins in lower and fewer charge states with color-coded charge-state clusters in contrast with denaturing conditions. Using only a single dimension of LC separation, co-elution of some proteins is inevitable (Figure $6 \mathrm{c}$ and $6 \mathrm{~d}$ ) and, therefore, fractionation and multi-dimensional separation are often employed. ${ }^{35} \mathrm{Here}$, for proof-ofconcept purposes, we used only one-dimension HIC-MS to demonstrate the online feasibility even with a complex cell lysate. Moreover, since the spectra contain fewer charge states than under denaturing conditions, the MS analysis becomes less complex. For larger size proteins in denaturing conditions, higher charge states fall into a low $\mathrm{m} / \mathrm{z}$ range, in which the distance between each charge state becomes narrow. This hinders deconvolution of the charge states at low intensity and with limited resolution. In contrast, non-denaturing conditions typically result in lower charge distribution of protein ions and a shift to a higher $\mathrm{m} / \mathrm{z}$ range, which enables easier assignment of the charge states for deconvolution (Figure 6c). Representative data for proteins ranging from $7.3 \mathrm{kDa}$ to $206 \mathrm{kDa}$ are shown in the insertions of Figure 6 b-e.

\section{DISCUSSION}

In this study, we have synthesized a new series of unusually hydrophobic HIC materials and demonstrated their successful online implementation of $\mathrm{HIC}-\mathrm{MS}$ with $\mathrm{NH}_{4} \mathrm{OAc}$ as the salt. Moreover, we have demonstrated the qualitative and quantitative potential of this HIC-MS method. HIC was known to be an orthogonal method that complements other separation techniques, ${ }^{35,38}$ and we have also demonstrated the orthogonal selectivity between the new HIC materials and RPC (Figure S6). The unique advantages of conventional HIC, including its non-denaturing character and remarkable sensitivity to structure variance, were retained online with the new HIC materials (Figure 5), expanding the online LC-MS toolbox for topdown proteomics and providing additional multi-dimensional options. The mass spectra of HIC-MS feature low charge state distribution, implying retention of native protein structures under these conditions. As demonstrated, this HIC-MS method provides alternative highresolution approach with minimal denaturation for cases where non-denaturing condition is preferred or cases where proteins cannot be eluted from RPC.

HIC is generally considered to be a non-denaturing mode of chromatography. However, a search of the literature discloses that this property is not absolute. ${ }^{42,47}$ The degree of protein denaturation is directly proportional to the time of contact with the hydrophobic stationary phase and inversely proportional to the starting concentration of salt in the mobile phase. ${ }^{47}$ The same observations pertain to proteins on reversed-phase surfaces. ${ }^{42}$ Success in HIC-MS, then, requires separation and elution of the proteins faster than the kinetics of denaturation using a volatile solvent. That seems to have been accomplished with these new hydrophobic HIC materials, provided that any solvent used for a gradient from starting conditions be one that suffices for elution. That probably means one that contains some organic solvent, since a gradient to a low-salt buffer without organic solvent might lead to denaturation of proteins caused by prolonged contact with the hydrophobic ligands without the structure-protecting effect of the high initial salt concentration. As a result, proteins can fail to elute (Figure 2a). 
The PolyPENTYL A, PolyHEXYL A, and PolyHEPTYL A materials introduced here appear to afford kinetics of elution that are faster than those of denaturation for most proteins using MS-compatible mobile phases. The involvement of high salt concentration also seems to further protect the tertiary structure from denaturation, but the ability of the salt to promote retention and protect structure do not necessarily correlate. ${ }^{42}$ In effect, at least from the observed mass spectra, proteins were in low charge states indicating predominantly native structures (Figure 4 and Figure 6).

With the MS-compatible salt $\mathrm{NH}_{4} \mathrm{OAc}$ and the presence of organic solvent in the final mobile phase, the operating mechanisms of the new materials remain incompletely understood and need further investigation. In conventional HIC, retention is strongly affected by ligand length and salt concentration. That was true here of Cyt and Lac but much less so for the other protein standards with the materials more hydrophobic than PolyBUTYL A, a behavior more characteristic of RPC. An interesting calorimetric study by Lin et al. suggests that retention of some protein standards by CM-butyl-Sepharose in $4 \mathrm{M}$ $\mathrm{NaCl}$ is an adsorption process while retention on CM-octyl-Sepharose involves both adsorption and partitioning. ${ }^{48}$ Lin et al. saw the same trend with an increase in ligand density. ${ }^{49}$ An observation more relevant to this study is that retention of isomorphs of apolipoprotein E were the same on columns with ethyl- and propyl- ligands. ${ }^{37}$ These apolipoproteins lack a well-defined tertiary structure, and so any hydrophobic domains in the proteins that are accessible to a propyl- ligand are also available to an ethyl- ligand. With proteins that do have well-defined tertiary structures, access to sequestered hydrophobic domains seems to increase with ligand length up to the pentyl- ligand. At that point, every hydrophobic domain of some proteins is accessible and so retention no longer increases significantly with the length of the ligands. This provides a possible explanation for the phenomenon we observed above. In the absence of a more detailed study of the mechanism, we tentatively call our conditions a HIC-RPC hybrid.

\section{CONCLUSION}

We have reported here the development of new HIC materials for online HIC-MS analysis of intact proteins. For the first time HIC and MS were directly coupled in an online fashion using volatile $\mathrm{NH}_{4} \mathrm{OAc}$ as the salt in the mobile phase. The standards examined eluted cleanly in well-shaped peaks, and the mass spectra of the proteins eluted from HIC resembled those of native mass spectra, implying minimal denaturation. Furthermore, we have demonstrated the use of HIC-MS for online separation and analysis of a complex cell lysate. This new HIC has some aspects of both RPC and conventional HIC: although it requires some organic solvent for elution, the salt in the mobile phase minimizes denaturation of proteins. Rather than promoting retention, the function of the salt primarily serves to protect the tertiary structure of the protein. Implementation of this method allows separation of proteins under generally non-denaturing conditions and adds options for multidimensional LC. This LC-MS combination could potentially be applied to the study of antibody-drug conjugates and larger macromolecular protein complexes in the future. 


\section{Supplementary Material}

Refer to Web version on PubMed Central for supplementary material.

\section{Acknowledgments}

We thank Zachery Gregorich, Ziqing Lin, Tania Guardado, and Zhijie Wu for the critical reading of the manuscript, Deyang Yu for growing E. coli cells, and Nathan Miklos for technical assistance with the chromatography. We also thank Jeremy Wolff, Lori Ann Upton, Allan Martinez, Mark Marispini, and Vladimir Ondruska at Bruker for technical assistance. We would like to acknowledge NIH grants, R01HL096971, R01HL109810, R01GM11705 and S10 OD01847 (to Y.G.).

\section{References}

1. Krueger KE, Srivastava S. Mol Cell Proteomics. 2006; 5:1799-1810. [PubMed: 16844681]

2. Karve TM, Cheema AK. J amino acids. 2011; 2011:207691. [PubMed: 22312457]

3. Chamot-Rooke J, Mikaty G, Malosse C, Soyer M, Dumont A, Gault J, Imhaus AF, Martin P, Trellet M, Clary G, Chafey P, Camoin L, Nilges M, Nassif X, Dumenil G. Science. 2011; 331:778-782. [PubMed: 21311024]

4. Ansong C, Wu S, Meng D, Liu XW, Brewer HM, Kaiser BLD, Nakayasu ES, Cort JR, Pevzner P, Smith RD, Heffron F, Adkins JN, Pasa-Tolic L. P Natl Acad Sci USA. 2013; 110:10153-10158.

5. Burnaevskiy N, Fox TG, Plymire DA, Ertelt JM, Weigele BA, Selyunin AS, Way SS, Patrie SM, Alto NM. Nature. 2013; 496:106-109. [PubMed: 23535599]

6. Zhang J, Guy MJ, Norman HS, Chen YC, Xu Q, Dong X, Guner H, Wang S, Kohmoto T, Young KH, Moss RL, Ge Y. J Proteome Res. 2011; 10:4054-4065. [PubMed: 21751783]

7. Dong X, Sumandea CA, Chen YC, Garcia-Cazarin ML, Zhang J, Balke CW, Sumandea MP, Ge Y. J Biol Chem. 2012; 287:848-857. [PubMed: 22052912]

8. Peng Y, Gregorich ZR, Valeja SG, Zhang H, Cai WX, Chen YC, Guner H, Chen AJ, Schwahn DJ, Hacker TA, Liu XW, Ge Y. Mol Cell Proteomics. 2014; 13:2752-2764. [PubMed: 24969035]

9. Ge Y, Rybakova IN, Xu Q, Moss RL. Proc Natl Acad Sci USA. 2009; 106:12658-12663. [PubMed: 19541641]

10. Gregorich ZR, Ge Y. Proteomics. 2014; 14:1195-1210. [PubMed: 24723472]

11. Chait BT. Science. 2006; 314:65-66. [PubMed: 17023639]

12. Smith LM, Kelleher NL. Consortium Top Down, P. Nat Methods. 2013; 10:186-187. [PubMed: 23443629]

13. Siuti N, Kelleher NL. Nat Methods. 2007; 4:817-821. [PubMed: 17901871]

14. Savaryn JP, Catherman AD, Thomas PM, Abecassis MM, Kelleher NL. Genome Med. 2013; 5:53. [PubMed: 23806018]

15. Garcia BA. J Am Soc Mass Spectrom. 2010; 21:193-202. [PubMed: 19942451]

16. Kelleher NL, Thomas PM, Ntai I, Compton PD, LeDuc RD. Expert Rev Proteomics. 2014; 11:649-651. [PubMed: 25347991]

17. Zhou H, Ning Z, Starr AE, Abu-Farha M, Figeys D. Anal Chem. 2012; 84:720-734. [PubMed: 22047528]

18. Armirotti A, Damonte G. Proteomics. 2010; 10:3566-3576. [PubMed: 20859958]

19. Cui W, Rohrs HW, Gross ML. Analyst. 2011; 136:3854-3864. [PubMed: 21826297]

20. Doucette AA, Tran JC, Wall MJ, Fitzsimmons S. Expert Rev Proteomics. 2011; 8:787-800. [PubMed: 22087661]

21. Zhang ZR, Wu S, Stenoien DL, Pasa-Tolic L. Annu Rev Anal Chem. 2014; 7:427-454.

22. Roth MJ, Plymire DA, Chang AN, Kim J, Maresh EM, Larson SE, Patrie SM. Anal Chem. 2011; 83:9586-9592. [PubMed: 22017354]

23. Tran JC, Zamdborg L, Ahlf DR, Lee JE, Catherman AD, Durbin KR, Tipton JD, Vellaichamy A, Kellie JF, Li M, Wu C, Sweet SM, Early BP, Siuti N, LeDuc RD, Compton PD, Thomas PM, Kelleher NL. Nature. 2011; 480:254-258. [PubMed: 22037311] 
24. Tian Z, Tolic N, Zhao R, Moore RJ, Hengel SM, Robinson EW, Stenoien DL, Wu S, Smith RD, Pasa-Tolic L. Genome Biol. 2012; 13:R86. [PubMed: 23034525]

25. Stobaugh JT, Fague KM, Jorgenson JW. J Proteome Res. 2013; 12:626-636. [PubMed: 23205614]

26. Vellaichamy A, Tran JC, Catherman AD, Lee JE, Kellie JF, Sweet SMM, Zamdborg L, Thomas PM, Ahlf DR, Durbin KR, Valaskovic GA, Kelleher NL. Anal Chem. 2010; 82:1234-1244. [PubMed: 20073486]

27. Strader MB, VerBerkmoes NC, Tabb DL, Connelly HM, Barton JW, Bruce BD, Pelletier DA, Davison BH, Hettich RL, Larimer FW, Hurst GB. J Proteome Res. 2004; 3:965-978. [PubMed: 15473684]

28. Eschelbach JW, Jorgenson JW. Anal Chem. 2006; 78:1697-1706. [PubMed: 16503625]

29. Young NL, DiMaggio PA, Plazas-Mayorca MD, Baliban RC, Floudas CA, Garcia BA. Mol Cell Proteomics. 2009; 8:2266-2284. [PubMed: 19654425]

30. Carroll J, Fearnley IM, Walker JE. P Natl Acad Sci USA. 2006; 103:16170-16175.

31. Tetaz T, Detzner S, Friedlein A, Molitor B, Mary JL. J Chromatogr A. 2011; 1218:5892-5896. [PubMed: 20926084]

32. Muneeruddin K, Nazzaro M, Kaltashov IA. Anal Chem. 2015; 87:10138-10145. [PubMed: 26360183]

33. Muneeruddin K, Thomas JJ, Salinas PA, Kaltashov IA. Anal Chem. 2014; 86:10692-10699. [PubMed: 25310183]

34. Chen X, Ge Y. Proteomics. 2013; 13:2563-2566. [PubMed: 23794208]

35. Valeja SG, Xiu L, Gregorich ZR, Guner H, Jin S, Ge Y. Anal Chem y. 2015; 87:5363-5371.

36. Queiroz JA, Tomaz CT, Cabral JMS. J Biotechnol. 2001; 87:143-159. [PubMed: 11278038]

37. Alpert AJ. J Chromatogr. 1986; 359:85-97.

38. Xiu L, Valeja SG, Alpert AJ, Song J, Ying G. Anal Chem. 2014; 86:7899-7906. [PubMed: 24968279]

39. Flick TG, Cassou CA, Chang TM, Williams ER. Anal Chem. 2012; 84:7511-7517. [PubMed: 22881839]

40. Gooding DL, Schmuck MN, Nowlan MP, Gooding KM. J Chromatogr. 1986; 359:331-337. [PubMed: 3733935]

41. Heck AJR. Nature Methods. 2008; 5:927-933. [PubMed: 18974734]

42. McNay JL, O'Connell JP, Fernandez EJ. Biotechnol Bioeng. 2001; 76:233-240. [PubMed: 11668459]

43. Jungbauer A, Machold C, Hahn R. J Chromatogr A. 2005; 1079:221-228. [PubMed: 16038308]

44. Loo JA, Benchaar SA, Zhang J. Mass Spectrom. 2013; 2:S0013.

45. Haverick M, Mengisen S, Shameem M, Ambrogelly A. Mabs-Austin. 2014; 6:852-858.

46. Di Donato A, Ciardiello MA, de Nigris M, Piccoli R, Mazzarella L, D’Alessio G. J Biol Chem. 1993; 268:4745-4751. [PubMed: 8444851]

47. Haimer E, Tscheliessnig A, Hahn R, Jungbauer A. J Chromatogr A. 2007; 1139:84-94. [PubMed: 17116304]

48. Lin FY, Chen WY, Ruaan RC, Huang HM. J Chromatogr A. 2000; 872:37-47. [PubMed: 10749485]

49. Lin FY, Chen WY, Hearn MTW. Anal Chem. 2001; 73:3875-3883. [PubMed: 11534710] 
a PolyPROPYLA

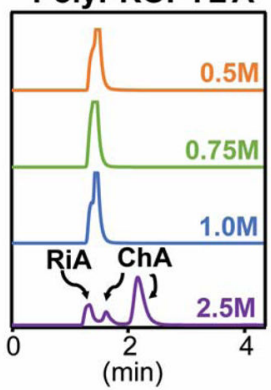

b

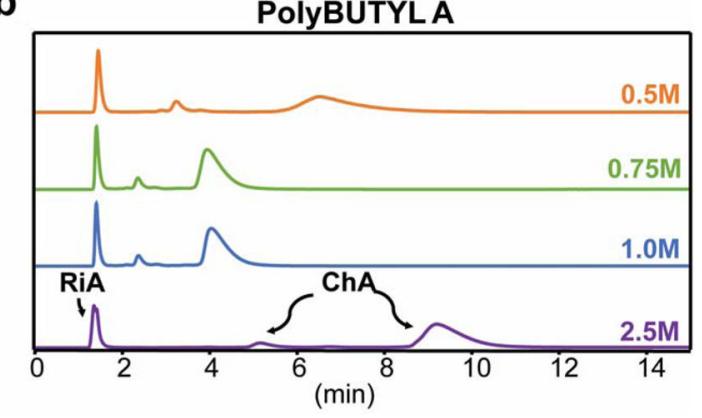

Figure 1.

Conventional HIC columns with $\mathrm{NH}_{4} \mathrm{OAc}$. UV chromatograms of RiA and ChA mixture using (a) PolyPROPYL A and (b) PolyBUTYL A from the indicated concentration of $\mathrm{NH}_{4} \mathrm{OAc}$ to $20 \mathrm{mM} \mathrm{NH}_{4} \mathrm{OAc}$ over a 15 min gradient. 

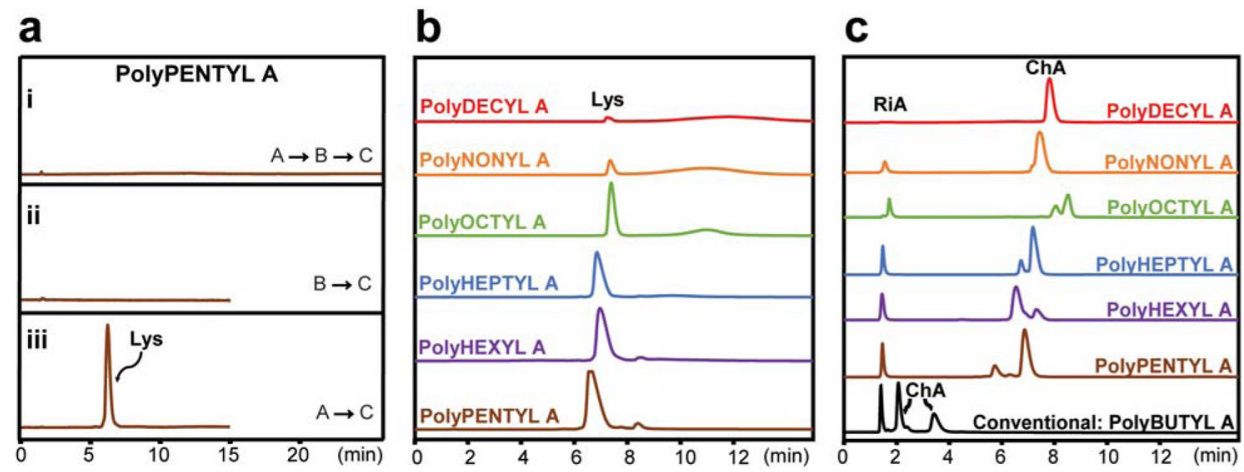

Figure 2.

Characterization of the new HIC materials. (a) Lys with PolyPENTYL A in three different elution gradient sequences. (i) 10 min gradient from $\mathrm{A}\left(2.5 \mathrm{M} \mathrm{NH}_{4} \mathrm{OAc}\right)$ to $\mathrm{B}(20 \mathrm{mM}$ $\left.\mathrm{NH}_{4} \mathrm{OAc}\right)$, then $10 \mathrm{~min}$ of gradient from B to $\mathrm{C}\left(20 \mathrm{mM} \mathrm{NH}{ }_{4} \mathrm{OAc}\right.$ with $\left.50 \% \mathrm{ACN}\right)$ followed by $5 \mathrm{~min}$ isocratic elution with $\mathrm{C}$. (ii) $10 \mathrm{~min}$ gradient from $\mathrm{B}$ to $\mathrm{C}$ followed by $5 \mathrm{~min}$ isocratic elution with $\mathrm{C}$. (iii) $10 \mathrm{~min}$ gradient from $\mathrm{A}$ to $\mathrm{C}$ followed by 5 min elution with $\mathrm{C}$. (b) Lys and (c) RiA and ChA mixture with different HIC columns; $1 \mathrm{M} \mathrm{NH}_{4} \mathrm{OAc}$ to $20 \mathrm{mM}$ $\mathrm{NH}_{4} \mathrm{OAc}$ with $50 \%$ ACN over a 15 min gradient. Detection: $280 \mathrm{~nm}$. 


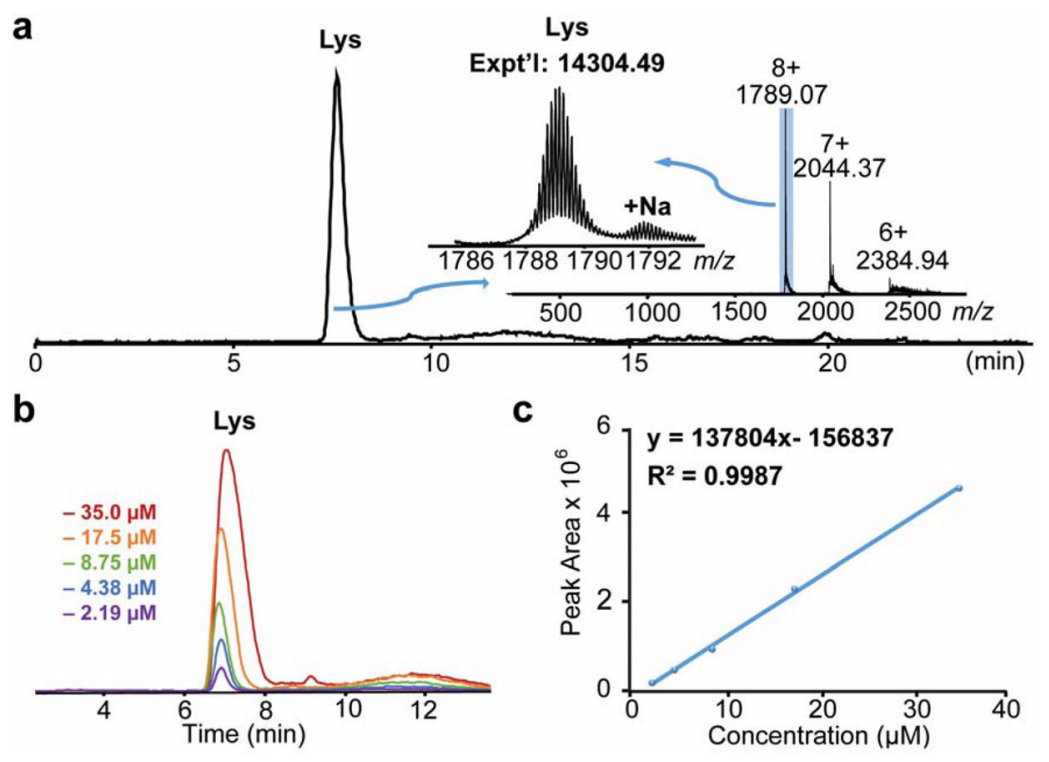

Figure 3.

Feasibility of online HIC-MS of a single protein for qualitative and quantative analysis. (a) Base peak chromatogram of $2 \mu \mathrm{L}$ of $0.06 \mathrm{mg} / \mathrm{mL}$ Lys; (b) overlaid HIC-MS chromatograms of serially diluted Lys in different concentrations and (c) working curve of serially diluted Lys with a PolyHEPTYL A capillary running from $1 \mathrm{M} \mathrm{NH}_{4} \mathrm{OAc}$ to $20 \mathrm{mM} \mathrm{NH}_{4} \mathrm{OAc}$ with $50 \% \mathrm{ACN}$ in a 15 min gradient followed by $20 \mathrm{mM} \mathrm{NH}_{4} \mathrm{OAc}$ with $50 \% \mathrm{ACN}$ for 5 min at 3 $\mu \mathrm{L} / \mathrm{min}$. Insert in (a): Mass spectrum of Lys and the zoom-in spectrum of the highlighted charge state. 


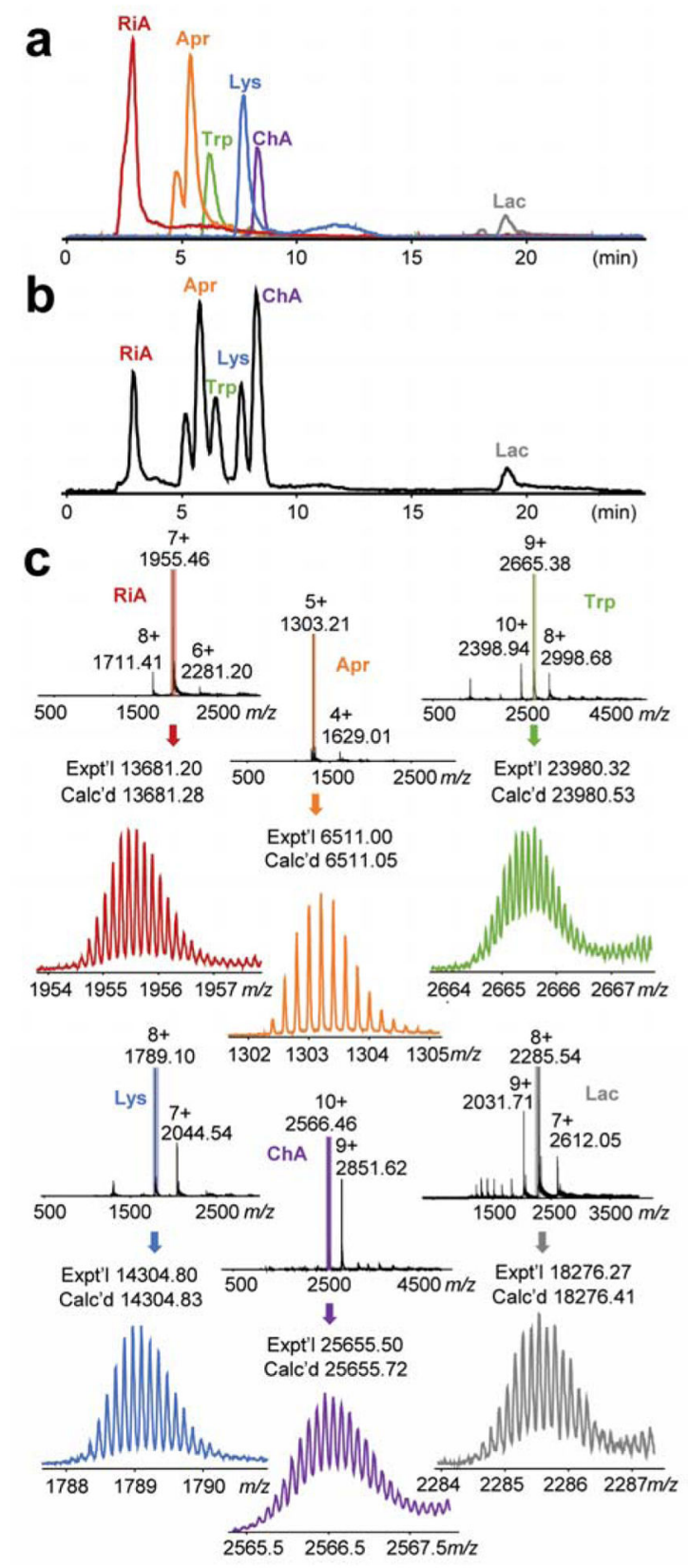

Figure 4.

HIC-MS run of a six-protein mixture on PolyHEPTYL A at $2.4 \mu \mathrm{L} / \mathrm{min}$; gradient as described in Figure 3. (a) Overlaid HIC-MS base peak chromatograms of individual proteins. (b) Base peak chromatogram of a six-protein mixture. (c) Charge state pattern and isotopic resolution of each protein on a chromatographic time scale. 


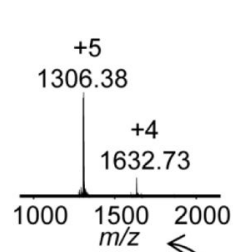

Apr

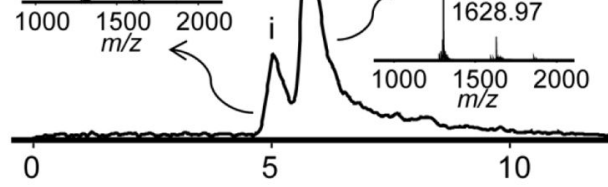

10

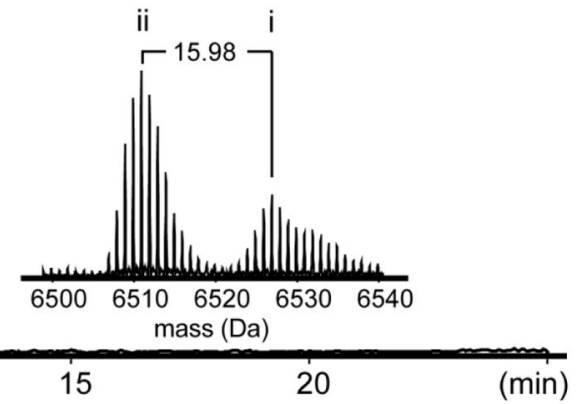

Figure 5.

HIC-MS of Apr with modified form. (a) Base peak chromatogram of Apr on PolyHEPTYL A with the same chromatographic conditions as described in Figure 4. Insert: mass spectra of two peaks (i and ii) of Apr and deconvoluted spectrum showing a 15.98 Da difference. 

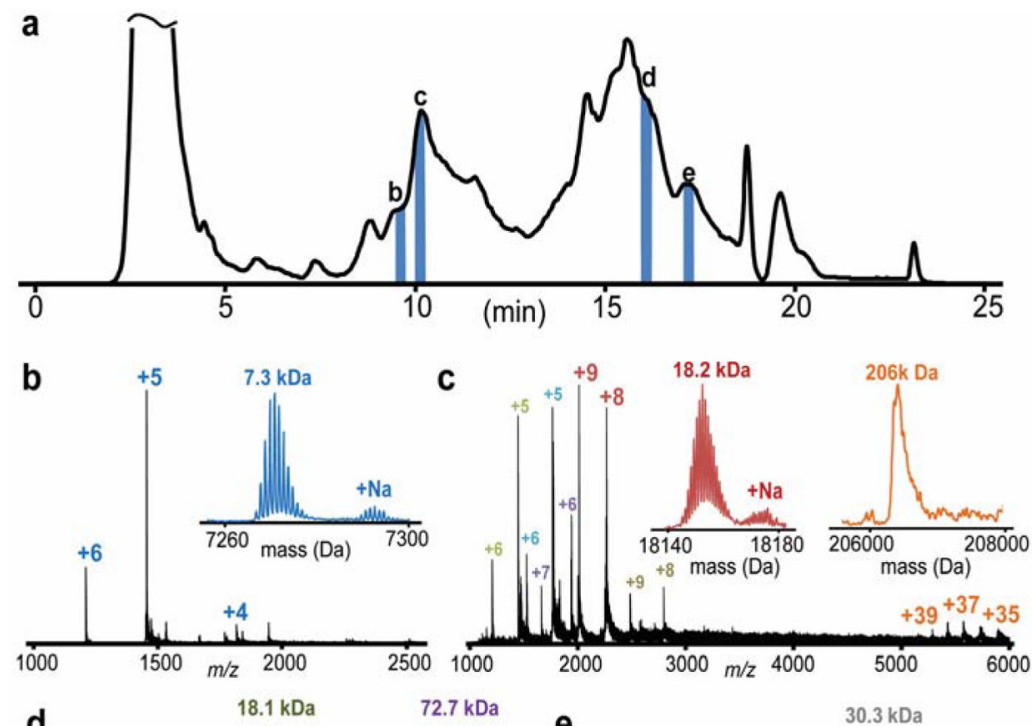

d
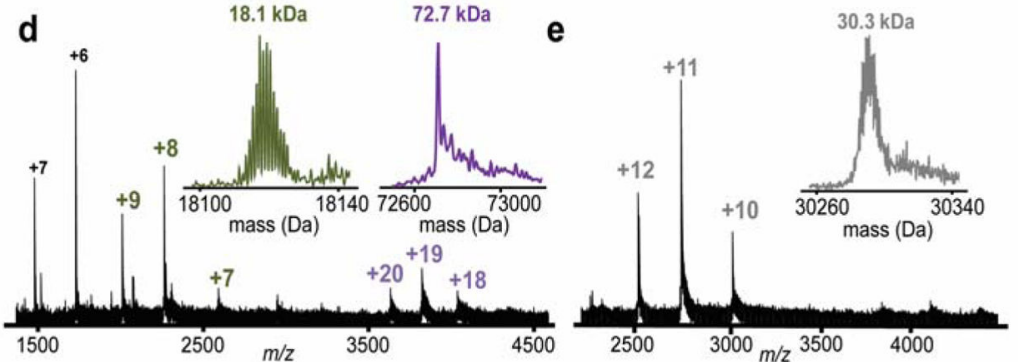

Figure 6.

HIC-MS run of E. coli cell lysate sample on PolyHEXYL A. Representative mass spectra are shown. (a) TIC (ten-fold zoom-in) of $E$. coli lysate by HIC separation with conditions as described in Figure 4. Average spectra and deconvoluted spectra from respective color-coded charge states from (b) 9.4 - $9.8 \mathrm{~min}$, (c) 10.0 - $10.4 \mathrm{~min}$, (d) 16.0 - $16.2 \mathrm{~min}$, (e) 17.0 - 17.3 $\min$. 